\title{
Kajian Ekologi Bentanglahan dan Persepsi Masyarakat terhadap Rencana Eksplorasi Panas Bumi
}

\author{
Agie S. Gizawi ${ }^{1}$, Su Ritohardoyo ${ }^{2}$ dan Eko Haryono ${ }^{3}$ \\ Fakultas Geografi, Universitas Gadjah Mada, Yogyakarta, Indonesia ${ }^{1,2,3}$ \\ Email koresponden:agies.gizawi@gmail.com
}

Diterima: 5 September 2017 /Disetujui: 14 Februari 2017 / Publikasi online: 31 Maret 2017

(C) 2017 Fakultas Geografi UGM dan Ikatan Geograf Indonesia (IGI)

\begin{abstract}
Abstrak Penelitian bertujuan untuk mengkaji perubahan ekologi bentanglahan dan kondisi sosial masyarakat (pengetahuan, persepsi, tingkat penerimaan) serta merumuskan strategi pengelolaan lingkungan mengenai rencana dan dampak lingkungan dari eksplorasi panas bumi WKP Gunung Ciremai. Kajian perubahan ekologi bentanglahan dianalisis dengan metode Spatial Landscape Impact Assesment (SLIA) dan kajian kondisi sosial masyarakat dilakukan dengan pengambilan data kuisioner serta depth interview. Strategi pengelolaan lingkungan dirumuskan dengan pendekatan Pressure-State-Response (PSR). Hasil penelitian biofisik merujuk pada tiga aspek bentanglahan yakni area permukaan, reduksi kawasan lingkungan penting dan fragmentasi. Area permukaan yang diprediksi akan berubah seluas 42.060 $\mathrm{m} 2$ dan 0,05549 km2 kawasan lingkungan penting yang didominasi oleh kebun campur akan tereduksi. Sedangkan fragmentasi yang akan terjadi mengakibatkan perubahan struktur bentanglahan karena terjadinya penambahan jumlah patch dan koridor. Kondisi sosial masyarakat menunjukkan bahwa mayoritas masyarakat tidak memiliki pemahaman yang cukup tentang rencana dan dampak eksplorasi panas bumi terhadap lingkungan. Masyarakat memiliki persepsi yang negatif terhadap rencana eksplorasi panas bumi sehingga $74 \%$ responden menyatakan menolak rencana eksplorasi panas bumi. Strategi pengelolaan lingkungan dianjurkan untuk dititikberatkan pada upaya subsitusi jasa ekosistem yang hilang akibat eksplorasi dan sosialisasi rencana intensif pada masyarakat.
\end{abstract}

Kata kunci: Panas bumi, Ekologi Bentanglahan, SLIA, Fragmentasi, Tingkat Pengetahuan, Tingkat Penerimaan, PSR

\begin{abstract}
The main purpose of this study is to assess the ecological landscape change in Mount Ciremai geothermal powerplant site and to examine public's knowledge, perception and social acceptance about geothermal powerplant exploration and its environmental impact. Also this study aims to formulate environmental management strategies based on the study of the landscape ecology and public perception about plan for geothermal exploration. This research was conducted in the Pajambon Village and Cisantana Village, Kuningan Regency. Ecological landscape change is analyzed by Spatial Landscape Impact Assesment (SLIA) and the social study was conducted using questionnaire approach and depth interview. Environmental management strategy was formulated using Pressure-State-Response (PSR) method. The results of ecological landscape change observed in three aspects: surface areas, reduction of environmentally important areas and landscape fragmentation. Geothermal exploration will transform the surface areas about 42,060 $\mathrm{m} 2$ and Mixed garden as environmentally important areas will be reducted by geothermal exploration about 0,05549 $\mathrm{km} 2$. While fragmentation will occur resulting in changes in the structure of the landscape due to the additional number of patches and corridors. Social conditions indicate that the majority of people lack of knowlodge of the geothermal exploration plans and the impact on environment. Public also have a negative perception of the geothermal exploration plan and that the public has a very low acceptance rate. It is shown from more than $74 \%$ respondent's stated that they refuse the plan of the geothermal exploration in this area. To that end, responses reflect a considerable lack of public information on the subject. Environmental management strategy will be focused on the substitution of ecological/ ecosystem services loss because of the exploration and intensify of plan's infomation to public.
\end{abstract}

Keywords: Geothermal, Landscape Ecology, SLIA, Fragmentation, Social Knowledge, Social Acceptance, PSR

\section{PENDAHULUAN}

Energi listrik merupakan kebutuhan vital bagi negara-negara dunia ketiga, termasuk Indonesia. Listrik memegang peranan penting dalam menunjang pertumbuhan ekonomi di hampir semua negara di dunia termasuk Indonesia. Secara umum, peningkatan kebutuhan energi listrik memiliki kaitan yang erat dengan dinamika kuantitas dan kualitas penduduk serta pertumbuhan kegiatan ekonomi (Soesetijo, 2013; Wei, et al., 2011; Widyastuti, 2006). Rencana pengembangan
PLTP G. Ciremai oleh ESDM dirasakan sebagai rencana alternatif sempurna bagi pemenuhan listrik di Indonesia terutama Jawa dan Bali. Pengembagan energi alternatif berupa panas bumi ini akan menimbulkan dampak terhadap lingkungan hidup. Dampak yang ditimbulkan dapat bersifat negatif atau merugikan terhadap lingkungan hidup, dapat juga berdampak positif atau menguntungkan bagi lingkungan hidup sekitar (Wangke, 2010). Dampak yang ditimbulkan oleh kegiatan pengembangan panas bumi antara lain 
pada komponen biofisik dan sosial ekonomi budaya masyarakat.

Tujuan dari penelitian ini adalah (1) Mengkaji perubahan ekologi bentanglahan yang akan terjadi akibat adanya rencana eksplorasi panas bumi di WKP Panas bumi Gunung Ciremai. (2) Mengkaji pengetahuan masyarakat mengenai rencana dan dampak lingkungan yang dapat timbul akibat adanya rencana eksplorasi panas bumi di WKP Panas bumi Gunung Ciremai. (3) Mengkaji persepsi dan tingkat penerimaan masyarakat mengenai rencana eksplorasi panas bumi di WKP Panas bumi Gunung Ciremai. (4) Merumuskan strategi pengelolaan lingkungan yang didasarkan pada kajian ekologi bentanglahan dan peresepsi masyarakat mengenai eksplorasi panas bumi.

\section{METODE PENELITIAN}

Penelitian dilakukan di dua desa yang termasuk kedalam area Wilayah Kerja Pertambangan (WKP) Panas bumi Gunung Ciremai yakni Desa Pajambon Kecamatan Kramatmulya dan Desa Cisantana Kecamatan Cigugur Kabupaten Kuningan Provinsi Jawa Barat pada Bulan Maret - Agustus 2015. Penelitian ini dilakukan dengan menggunakan mix methods, yaitu suatu langkah penelitian yang mengkombinasikan dua bentuk pendekatan, yaitu penelitian kuantitaif dan penelitian kualitatif (Creswell, 2010). Penggunaan metode ini dilakukan agar data yang diperoleh lebih komprehensif, valid, reliabel dan objektif (Sugiyono, 2011). Metode kuantitatif digunakan untuk menjawab tujuan pertama yaitu analisis perubahan ekologi bentanglahan menggunakan metode Spatial Landscape Impact Assesment (SLIA) rating system. Untuk menjawab tujuan kedua dan ketiga yaitu pengkajian pengetahuan, persepsi dan tingkat penerimaan masyarakat terhadap rencana eksplorasi panas bumi dilakukan dengan menggunakan mix method triangulation convergence model.

Pendekatan perubahan bentanglahan dilakukan dengan metode deskriptif analisis dan metode Spatial Landscape Impact Assesment (SLIA) rating system. Berdasar pada tiga aspek spasial-visual bentang lahan: (a) area permukaan, (b) Reduksi Kawasan Lingkungan Penting, (b) fragmentasi. Sementara untuk kajian tingkat pengetahuan, persepsi dan tingkat penerimaan masyarakat dilakukan menggunakan kuesioner dan depth interview.

\section{Area permukaan}

Perubahan permukaan atau penggunaan lahan akibat eksplorasi adalah indikator penting dalam pengukuran potensi perubahan bentanglahan. Tujuan dari analisis aspek ini adalah untuk untuk melihat total wilayah yang dibutuhkan dalam kegiatan eksplorasi panas bumi, perhitungan wilayah meliputi pembukaan titik-titik eksplorasi dan rencana jaringan jalan. Total wilayah dinyatakan dalam satuan $\mathrm{m} 2$ dengan menggunakan salah satu tools pada perangkat analisis spasial yakni buffer. Area seluas $1 \mathrm{~m}$ x $1 \mathrm{~m}$ dijadikan patokan perhitungan dan digabungkan menjadi total area permukaan yang dibutuhkan oleh satu kesatuan wilayah kerja panas bumi. Berdasarkan Otsman (2015) total area permukaan dikategorikan menjadi enam klasifikasi pengaruh yang akan menjadi salah satu indikator perubahan lanskap akibat kegiatan eksplorasi panas bumi (Tabel 1).

\section{Reduksi Kawasan Lingkungan Penting}

Tujuan dari pengukuran aspek ini adalah untuk menentukan luasan kawasan lingkungan penting terutama kawasan hutan atau area berfungsi hutan yang tereduksi karena kegiatan eksplorasi panas bumi. Untuk melakukan analisis, dibutuhkan peta penggunaan lahan di area sekitar kegiatan eksplorasi, kemudian dilakukan deliniasi area mana yang merupakan kawasan hutan dan kawasan berfungsi hutan sesuai dengan ketentuan yang berlaku. Semua kawasan tersebut dikelompokan menjadi satu layer poligon shapefile yang akan di overlay dengan peta kawasan eksplorasi dari rencana titik eksplorasi hingga rencana jaringan jalan. Selanjutnya, daerah yang beririsan akan dihitung luasannya sehingga dapat diketahui berapa luas kawasan lingkungan pentingan yang tereduksi akibat kegiatan eksplorasi panas bumi, hasil perhitungan luasan akan diklasifikasian ke dalam rating pengaruh numerik berdasarkan tabel 1 .

\section{Fragmentasi Bentanglahan}

Pengukuran pada aspek bentanglahan ini bertujuan untuk melihat jumlah fragmen yang terbentuk akibat adanya kegiatan eksplorasi panas bumi. Penambahan jumlah fragmen dapat diakibatkan dari pembukaan lahan di titik eksplorasi, pembukaan jalan atau pun konstruksi pipa penyalur panas bumi. Perhitungan fragmentasi dilakukan dengan membuat buffer area dari titik eksplorasi panas bumi seluas $20000 \mathrm{~m} 2$ dan jaringan jalan yang memiliki lebar buffer area 4 $\mathrm{m}$. Hasil interseksi kedua peta akan menghasilkan poligon-poligon fragmen dan selanjutnya dilakukan perhitungan untuk menunjukan jumlah fragmen yang terbentuk. Total jumlah fragmen akan diklasifikasikan ke dalam tabel skala 1 dan menentukan tingkat potensi transformasi dari kawasan eksplorasi.

Setelah ketiga aspek dianalisis dan diketahui nilai ratingnya, dalam penelitian SLIA ketiga nilai tersebut dijumlahkan dan menjadi bentuk angka perbandingan rating pengaruh yang terjadi dengan rating pengaruh maksimal. Hasil akhir sistem rating SLIA pada penelitian Otsman (2015) dinyatakan dalam bentuk angka yang menggambarkan perbandingan hasil total rating pengaruh numerik dan total nilai numerik tertinggi. Untuk dapat memudahkan proses interpretasi data, hasil skor metode SLIA diklasifikasikan kedalam rentang tingkat dampak yang dilakukan dengan cara menghitung nilai rata rata dari ketiga aspek bentanglahan yang diamati. Tabel 2 menunjukan tingkat 


\begin{tabular}{|c|c|c|c|}
\hline Aspek Perubahan Bentanglahan & $\begin{array}{l}\text { Rating Pengaruh } \\
\text { Numerik }\end{array}$ & Luas Perubahan Area Permukaan & Deskripsi Dampak \\
\hline \multirow[t]{6}{*}{ Area Permukaan } & 0 & $0 \mathrm{~m} 2$ & Tidak berdampak \\
\hline & 1 & $1-449.000 \mathrm{~m} 2$ & Berdampak Sangat Rendah \\
\hline & 4 & $450.000-649.000 \mathrm{~m} 2$ & Berdampak Rendah \\
\hline & 8 & $650.000-849.000 \mathrm{~m} 2$ & Berdampak Signifikan \\
\hline & 13 & $850.000-1.049 .000 \mathrm{~m} 2$ & Berdampak Tinggi \\
\hline & 20 & $\geq 1.050 .000 \mathrm{~m} 2$ & Berdampak Sangat Tinggi \\
\hline \multirow{6}{*}{$\begin{array}{l}\text { Reduksi Kawasan Lingkungan } \\
\text { Penting }\end{array}$} & 0 & $0 \mathrm{~km} 2$ & Tidak berdampak \\
\hline & 1 & $0,1-1,0 \mathrm{~km} 2$ & Berdampak Sangat Rendah \\
\hline & 4 & $1,1-1,5 \mathrm{~km} 2$ & Berdampak Rendah \\
\hline & 8 & $1,6-2,0 \mathrm{~km} 2$ & Berdampak Signifikan \\
\hline & 13 & $2,1-2,5 \mathrm{~km} 2$ & Berdampak Tinggi \\
\hline & 20 & $\geq 2,5 \mathrm{~km} 2$ & Berdampak Sangat Tinggi \\
\hline \multicolumn{4}{|l|}{ Fragmentasi } \\
\hline \multirow[t]{6}{*}{ Bentanglahan } & 0 & 0 patch & Tidak berdampak \\
\hline & 1 & $1-74$ patches & Berdampak Sangat Rendah \\
\hline & 4 & 75 - 99 patches & Berdampak Rendah \\
\hline & 8 & $100-124$ patches & Berdampak Signifikan \\
\hline & 13 & 125 - 149 patches & Berdampak Tinggi \\
\hline & 20 & $\geq 150$ patches & Berdampak Sangat Tinggi \\
\hline
\end{tabular}

(Sumber: Otsman, 2015)

Tabel 2. Rentang Skala Penentuan Tingkat Dampak Eksploitasi

\begin{tabular}{ll}
\hline Rentang Skala Rata-rata & Deskripsi Dampak \\
\hline $0-0,99$ & Tidak berdampak \\
$1-3,99$ & Berdampak Sangat Rendah \\
$4-7,99$ & Berdampak Rendah \\
$8-12,99$ & Berdampak Signifikan \\
$13-19,99$ & Berdampak Tinggi \\
$\geq 20$ & Berdampak Sangat Tinggi \\
\hline (Otsman 2015 dengan modifikasi, didasarkan pada Master Plan \\
Pengembangan Panas bumi Islandia)
\end{tabular}

dampak eksplorasi didasarkan pada tabel rating yang tercantum dalam Otsman (2015) yang dimodifikasi menjadi rentang skor.

Penggunaan mix method triangulation convergence model untuk analisis persepsi masyarakat dilakukan melalui pengambilan data primer menggunakan kuesioner pada 174 responden yang terdiri dari 86 kepala keluarga yang berasal dari Desa Pajambon dan 98 kepala keluarga berasal dari dari Desa Cisantana. Kuisioner kemudian diintrepetasikan menjadi data tabular melalui metode skoring untuk menghasilkan tingkat pengetahuan, persepsi dan penerimaan masyarakat. Sementara depth interview dilakukan pada aparat pemerintah kecamatan, desa dan tokoh masyarakat.

\section{HASIL DAN PEMBAHASAN}

Berdasarkan data yang diperoleh, terdapat dua titik potensial eksplorasi panas bumi. Titik pertama berada di Desa Pajambon pada koordinat 6 56' 19.63" LS - $108^{\circ} 26^{\prime} 54.7^{\prime \prime}$ BT dengan ketinggian 837,5 mdpl. Titik kedua juga terletak di Desa Pajambon namun berbatasan langsung dengan Desa Cisantana tepatnya pada koordinat $6^{\circ} 56^{\prime} 31.04^{\prime \prime}$ LS - $108^{\circ} 26^{\prime} 52.09^{\prime \prime}$ BT dan terletak pada ketinggian 925 mdpl. Seperti yang nampak pada Gambar 1.

Kegiatan eksplorasi akan menyebabkan perubahan pada kondisi lingkungan alami dan bentanglahan yang saat ini ada. Perubahan-perubahan tersebut dapat menimbulkan dampak lingkungan yang perlu diwaspadai, tiga aspek bentang lahan diamati dalam penelitian ini untuk melihat seberapa besar 


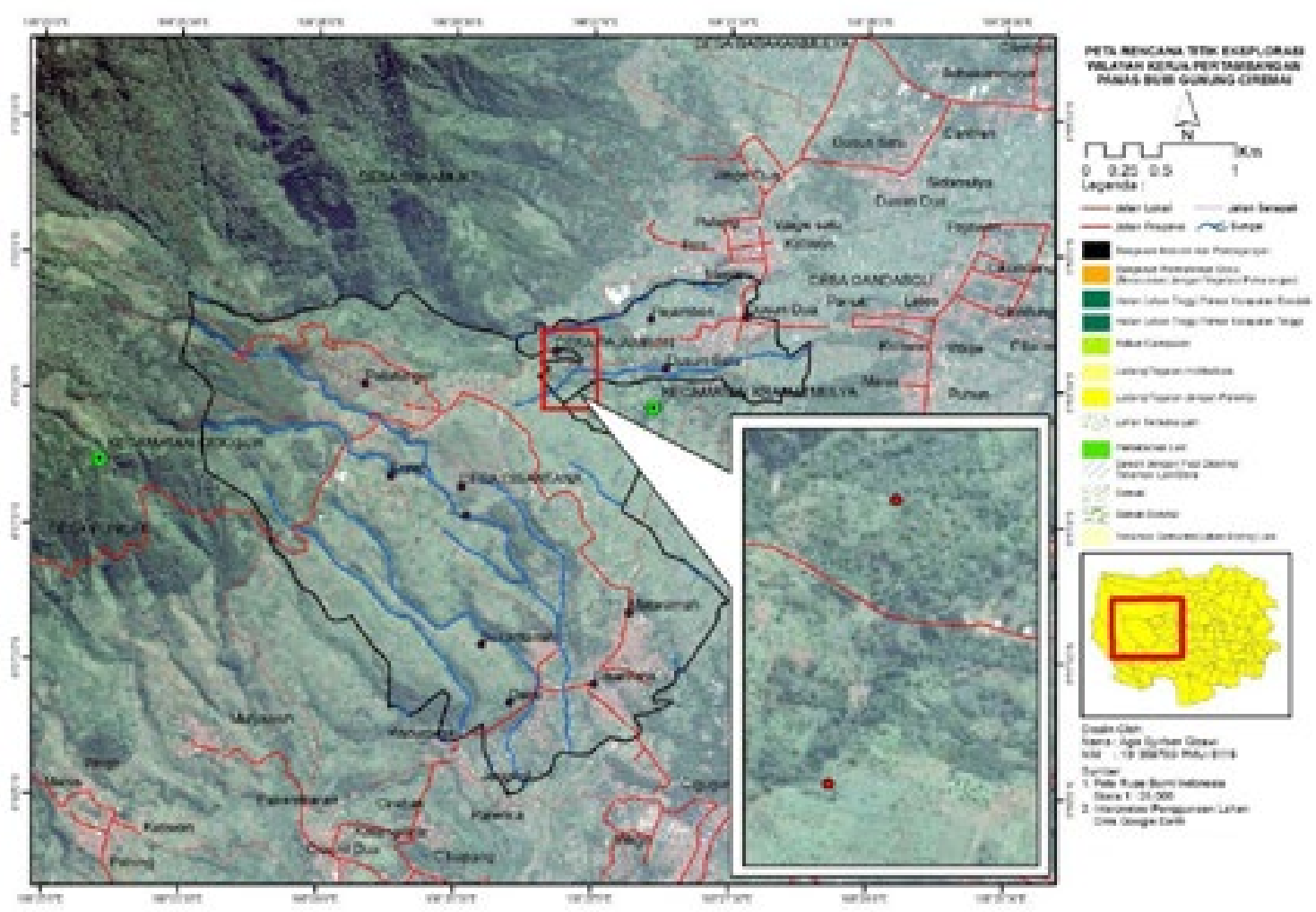

Gambar 1. Peta Lokasi Titik Panas bumi WKP Panas bumi Gunung Ciremai (Citra Geoeye, 2015)

dampak kegiatan terhadap kondisi lingkungan dan bentang lahan. Tiga aspek tersebut adalah perubahan permukaan, reduksi kawasan lingkungan penting dan fragmentasi.

Perubahan permukaan pada bentanglahan akibat eksplorasi panas bumi merupakan salah satu indikator penting dalam kajian perubahan ekologi bentanglahan. Tabel. 3 memunjukan bahwa berdasarkan hasil pengukuran, jumlah total perubahan area permukaan akibat kegiatan eksplorasi sebanyak 42.060 Ha sehingga memiliki rating 1 pada perhitungan metode SLIA. Perubahan permukaan mayoritas terjadi pada tutupan lahan kebun campur dan semak belukar yang berubah menjadi area terbuka atau jaringan jalan.

Aspek bentanglahan kedua yang diamati adalah reduksi kawasan lingkungan penting. Reduksi kawasan lingkungan penting ini berkaitan erat dengan perubahan area permukaan yang terjadi, berubahnya suatu tutupan lahan dari area bervegetasi menjadi lahan terbuka akan merubah fungsi ekologis lahan tersebut. Hal ini terjadi karena hilangnya fungsi vegetasi yang secara efektif dapat mengabsorbsi air hujan, mempertahankan laju infiltrasi (Foth, 1984), meningkatkan laju infiltrasi (Schwab, 1997), dan kemampuan dalam menahan air (kapasitas retensi air/KRA) (Utaya, 2008).

Berbanding lurus dengan dampak yang terjadi akibat perubahan area permukaan, berdasarkan skala rating SLIA, reduksi kawasan lingkungan penting yang dapat terjadi di titik eksplorasi panas bumi WKP G. Ciremai juga memiliki rating 1 atau memberikan dampak yang sangat rendah terhadap perubahan ekologi bentanglahan. Rincian reduksi kawasan penting akibat kegiatan eksplorasi dipaparkan dalam Tabel 4.

Meskipun berdasarkan skala rating SLIA reduksi kawasan lingkungan penting akibat eksplorasi panas bumi tergolong kedalam dampak sangat rendah, hilangnya area berupa kebun campur tetap akan memberikan pengaruh karena kebun campuran merupakan penggunaan lahan yang telah lama dikembangkan masyarakat. Kebun campuran yang umumnya dikembangkan dalam bentuk agroforestry dipandang mempunyai kemampuan dalam memenuhi fungsi ekologi, ekonomi dan sosio kultural masyarakat (Nair, 1993).

Menurut Handayani dan Indrajaya (2007 dalam Handayani, et. Al, 2009), hutan yang dikelola rakyat dalam bentuk kebun campuran/ agroforestry memiliki jasa lingkungan berupa mengurangi resiko terjadinya bencana (mitigasi) banjir di musim penghujan dan bencana kekeringan di musim kemarau, mengurangi resiko terjadinya bencana (mitigasi) tanah longsor, menyediakan dan melindungi keanekaragaman hayati serta penyerap karbon dan menjaga kualitas air/ penghasil air bersih.

Aspek bentanglahan ketiga yang diamati adalah fragmentasi. Aspek bentanglahan berupa fragmentasi atau munculnya patch, matrik dan koridor dapat ditimbullkan oleh adanya gangguan (disturbance). Fragmentasi akan meningkatkan kerawanan terhadap gangguan eksternal, misalnya gangguan badai dan kekeringan. Fragmentasi yang dapat terjadi pada lokasi titik satu eksplorasi panas bumi WKP G Ciremai adalah 
Agie S. Gizawi, dkk/Majalah Geografi Indonesia, Vol. 31 No.1, Maret $2017: 1$ - 11

Tabel 3. Pengukuran dan Hasil Rating SLIA di Titik Eksplorasi WKP. Gunung Ciremai pada Aspek Area Permukaan

\begin{tabular}{llll}
\hline $\begin{array}{l}\text { Kriteria Perubahan Ekologi Ben- } \\
\text { tanglahan }\end{array}$ & $\begin{array}{l}\text { Komponen Rencana } \\
\text { Eksplorasi }\end{array}$ & Satuan Perubahan & Total Perubahan (m2) \\
\hline Area Permukaan & Titik Eksplorasi 1 & 20.000 & 20.000 \\
& Titik Eksplorasi 2 & 20.000 & 20.000 \\
& Jaringan Jalan 1 & $4 \times 265$ & 1.060 \\
& Jaringan Jjalan 2 & $4 \times 250$ & 1.000 \\
Total Area Permukaan (m2) & 42.060 & & \\
\hline Rating Pengaruh Numerik SLIA & 1 & & \\
\hline
\end{tabular}

(Sumber: Data Primer, 2016)

Tabel 4. Pengukuran dan Hasil Rating SLIA di Titik Eksplorasi WKP. Gunung Ciremai pada Aspek Reduksi Kawasan Lingkungan Penting

\begin{tabular}{|c|c|c|c|}
\hline $\begin{array}{l}\text { Kriteria Perubahan Ekologi Ben- } \\
\text { tanglahan }\end{array}$ & Jenis Kawasan Penting & Satuan Perubahan & $\begin{array}{l}\text { Total Perubahan } \\
(\mathrm{km} 2)\end{array}$ \\
\hline \multirow[t]{6}{*}{ Reduksi Kawasan Penting } & Kebun Campur Titik Eksplorasi 1 & 0,01833 & 0,01833 \\
\hline & Semak Belukar Titik Eksplorasi 1 & 0,01740 & 0,01740 \\
\hline & Kebun Campur Titik Eksplorasi 2 & 0,01282 & 0,01282 \\
\hline & $\begin{array}{l}\text { Sawah dengan diselingi tanaman } \\
\text { lain atau bera Titik Eksplorasi } 2\end{array}$ & 0,006747 & 0,00674 \\
\hline & Jaringan jalan titik eksplorasi 1 & $4 \mathrm{~m} \times 265 \mathrm{~m}$ & 0,00010 \\
\hline & Jaringan jalan titik eksplorasi 2 & $4 \mathrm{~m} \times 250 \mathrm{~m}$ & 0,00010 \\
\hline $\begin{array}{l}\text { Total Reduksi Kawasan Penting } \\
(\mathrm{km} 2)\end{array}$ & 0,05549 & & \\
\hline Rating Pengaruh Numerik SLIA & 1 & & \\
\hline
\end{tabular}

patch pada matrik berupa kebun campur dan semak belukar. Selain itu, rencana jaringan jalan juga akan menimbulkan fragmentasi berupa koridor pada matrik yang merupakan kebuncampur. Fragmentasi yang berpotensi terjadi akibat adanya aktivitas eksplorasi panas bumi dijabarkan pada Tabel 5 dan Gambar 2.

Berdasarkan skala rating SLIA, gangguan yang ditimbulkan sehingga meneyebabkan struktur bentanglahan menjadi heterogen dan terfragmentasi memiliki rating 1 atau dapat dikatakan memberikan dampak yang sangat rendah. Walau secara analisis dampak fragmentasi kegiatan eksplorasi sangat rendah, perlu diperhatikan bahwa fragmentasi memiliki dampak langsung terhadap organisme. Fragmentasi habitat akan merubah beberapa aspek tingkah laku hewan, seperti pergerakan dan pencarian makan. Lebih jauh, fragmentasi yang mempengaruhi besaran patch dan matrik akan mempengaruhi keragaman fauna di daerah tersebut. Fragmen yang besar akan memelihara keragaman jenis dengan lebih baik, sedangkan fragmen yang kecil akan terbatas untuk sedikit jenis dan biasanya hanya jenis yang generalis. Fragmentasi akan berdampak yang sangat besar pada daerah topis yang memiliki lebih banyak jenis spesialis dibandingkan dengan daerah temperata (Farina, 1998).
Secara teori fragmentasi yang akan diakibatkan dari aktivitas pengembangan WKP G. Ciremai berpotensi meningkatkan kerawanan terhadap gangguan eksternal, misalnya gangguan badai dan kekeringan dan merubah habitat serta memengaruhi keberlanjutan fauna yang mendiami bentanglahan tersebut. Namun berdasar SLIA, fragmentasi dan dua faktor perubahan bentanglahan lain yang diamati masih dalam batas aman karena kegiatan eksplorasi tidak memberikan dampak besar bagi perubahan bentang alam dan kondisi sekitar lokasi.

\section{Karakteristik Responden}

Desa Pajambon dan Desa Cisantana adalah desa terpilih sebagai lokasi pengambilan data sosial pada penelitian ini. Berdasarkan perhitungan jumlah sampel, 98 responden terpilih dari Desa Pajambon dan 87 responden terpilih dari Desa Cisantana. Profil responden kedua desa dipaparkan dalam gambar 3.

Responden kedua desa di dominasi oleh ibu rumah tangga dengan latar belakang pendidikan Sekolah Dasar (SD) dan berusia di atas 51 tahun. 63\% responden dari Desa Pajambon dan 55\% responden Desa Cisantana adalah perempuan. Dominansi responden perempuan sebagai wakil dari unit populasi kepala keluarga terjadi 


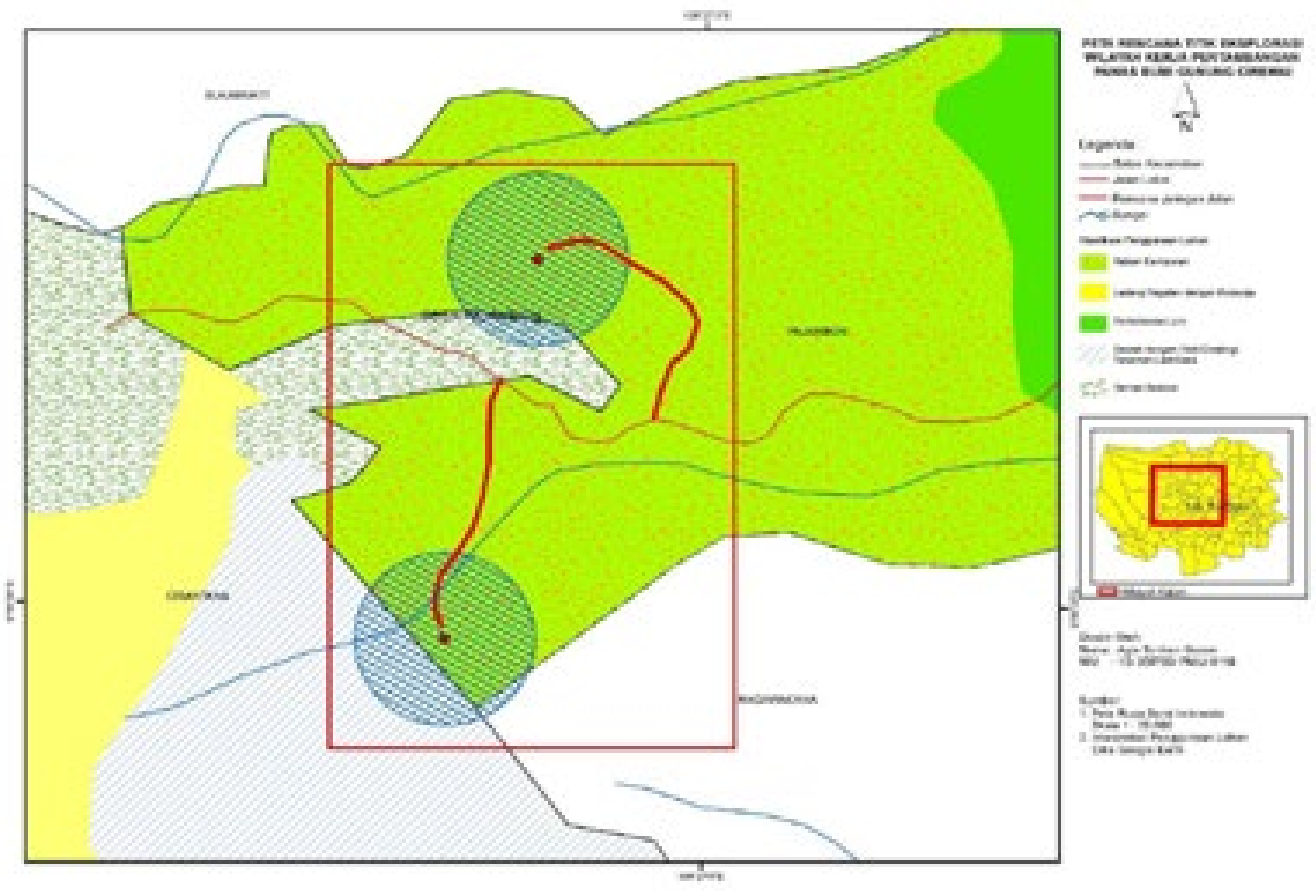

Gambar 2. Peta Fragmentasi Bentanglahan pada Lokasi Titik Panas bumi WKP Panas bumi Gunung

a

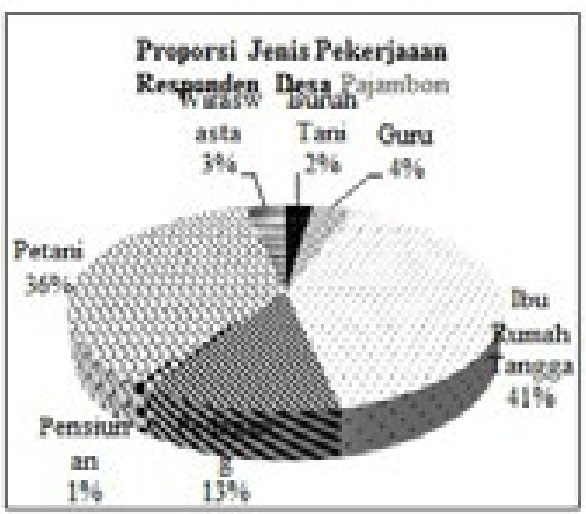

c.

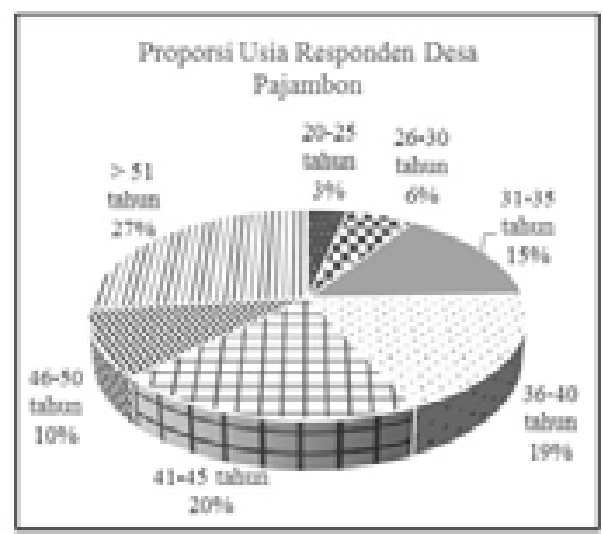

b.

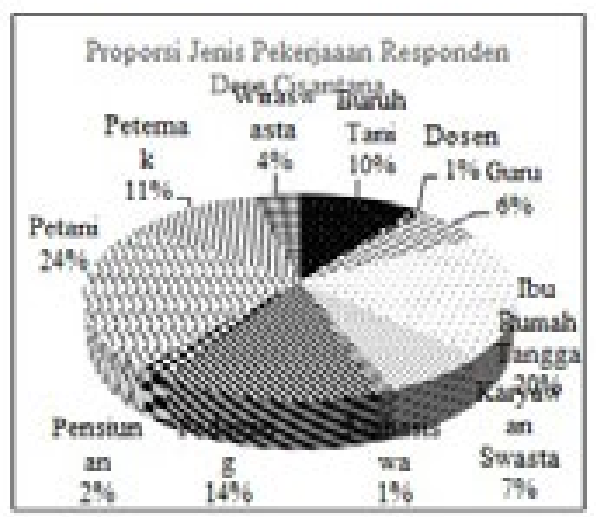

a

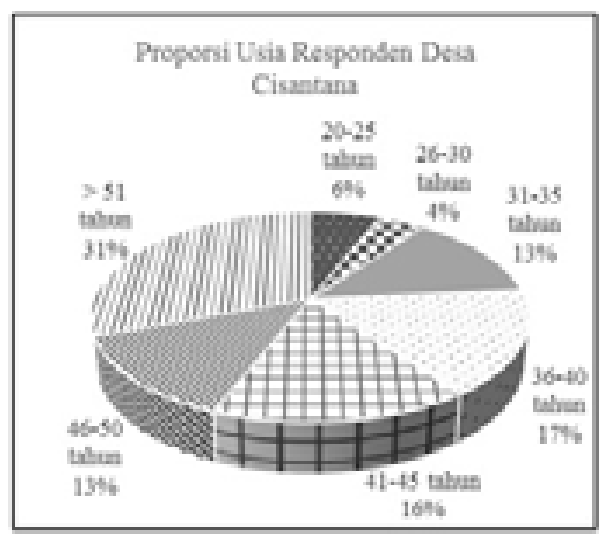

Gambar 3. Karakteristik Responden Penelitian (a) Proporsi Jenis Pekerjaaan Responden Desa Pajambon; (b) Proporsi Jenis Pekerjaaan Responden Desa Cisantana; (c) Proporsi Usia Responden Desa Pajambon; (d) Proporsi Usia Responden Desa Cisantana 
Agie S. Gizawi, dkk/Majalah Geografi Indonesia, Vol. 31 No.1, Maret 2017 : 1 - 11

Tabel 5. Pengukuran dan Hasil Rating SLIA di Titik Eksplorasi WKP. Gunung Ciremai pada Aspek Fragmentasi Bentanglahan

\begin{tabular}{llll}
\hline $\begin{array}{l}\text { Kriteria Perubahan } \\
\text { Ekologi Bentanglahan }\end{array}$ & $\begin{array}{l}\text { Komponen Rencana } \\
\text { Ekspolrasi }\end{array}$ & Satuan Perubahan & Total Perubahan (patch) \\
\hline $\begin{array}{l}\text { Jumlah Fragmentasi Ben- } \\
\text { tanglahan }\end{array}$ & Titik Eksplorasi 1 & 1 & 1 (patch) \\
& $\begin{array}{l}\text { Titik Eksplorasi 2 } \\
\text { Jaringan Jalan 1 }\end{array}$ & 1 & 1 (patch) \\
& Jaringan Jjalan 2 & 1 & 1 (koridor) \\
& 4 & & 1 (koridor) \\
$\begin{array}{l}\text { Total Fragmentasi Ben- } \\
\text { tanglahan (m2) }\end{array}$ & & & \\
$\begin{array}{l}\text { Rating Pengaruh Numer- } \\
\text { ik SLIA }\end{array}$ & 1 & & \\
(Sumber: Data Primer, 2016) & &
\end{tabular}

Tabel 6. Tingkat Pengetahuan Masyarakat Terhadap Rencana Eksplorasi Panas bumi di Desa Pajambon dan Desa Cisantana

\begin{tabular}{|c|c|c|c|c|c|c|}
\hline \multirow[t]{2}{*}{ Aspek Pengetahuan } & \multicolumn{2}{|c|}{$\begin{array}{c}\text { Persentase (\%) Desa Pa- } \\
\text { jambon }\end{array}$} & \multirow[t]{2}{*}{ Kategori } & \multicolumn{2}{|c|}{ Persentase (\%) Desa Cisantana } & \multirow[t]{2}{*}{ Kategori } \\
\hline & Mengetahui & $\begin{array}{l}\text { Tidak Meng- } \\
\text { etahui }\end{array}$ & & Mengetahui & Tidak Mengetahui & \\
\hline $\begin{array}{l}\text { Rencana Eksplorasi } \\
\text { Panas bumi }\end{array}$ & $93 \%$ & $7 \%$ & $\begin{array}{l}\text { Pengetahuan } \\
\text { Cukup }\end{array}$ & $94 \%$ & $6 \%$ & Pengetahuan Cukup \\
\hline $\begin{array}{l}\text { Lokasi Eksplorasi Panas } \\
\text { bumi }\end{array}$ & $67 \%$ & $47 \%$ & $\begin{array}{l}\text { Pengetahuan } \\
\text { Kurang }\end{array}$ & $58 \%$ & $42 \%$ & Pengetahuan Cukup \\
\hline $\begin{array}{l}\text { Pemrakarsa Eksplorasi } \\
\text { Panas bumi }\end{array}$ & $60 \%$ & $40 \%$ & $\begin{array}{l}\text { Pengetahuan } \\
\text { Kurang }\end{array}$ & $59 \%$ & $41 \%$ & Pengetahuan Kurang \\
\hline $\begin{array}{l}\text { Sosialisasi Eksplorasi } \\
\text { Panas bumi }\end{array}$ & $6 \%$ & $94 \%$ & $\begin{array}{l}\text { Pengetahuan } \\
\text { Kurang }\end{array}$ & $16 \%$ & $84 \%$ & Pengetahuan Kurang \\
\hline Rataan & $57 \%$ & $47 \%$ & $\begin{array}{l}\text { Pengetahuan } \\
\text { Kurang }\end{array}$ & $64 \%$ & $36 \%$ & Pengetahuan Kurang \\
\hline
\end{tabular}

(Sumber: Data Primer, 2016)

Tabel 7. Tingkat Pengetahuan Masyarakat Terhadap Definisi dan Pengaruh Eksplorasi Panas Bumi di Desa Pajambon dan Desa Cisantana

\begin{tabular}{|c|c|c|c|c|c|c|}
\hline \multirow[t]{2}{*}{ Aspek Pengetahuan } & \multicolumn{2}{|c|}{ Persentase (\%) Desa Pajambon } & \multirow[t]{2}{*}{ Kategori } & \multicolumn{2}{|c|}{ Persentase (\%) Desa Cisantana } & \multirow[t]{2}{*}{ Kategori } \\
\hline & Mengetahui & Tidak Mengetahui & & Mengetahui & Tidak Mengetahui & \\
\hline Pengertian Panas Bumi & $28 \%$ & $72 \%$ & $\begin{array}{l}\text { Pengetahuan } \\
\text { Kurang }\end{array}$ & $36 \%$ & $64 \%$ & $\begin{array}{l}\text { Pengetahuan } \\
\text { Kurang }\end{array}$ \\
\hline $\begin{array}{l}\text { Ciri Lokasi Ketersediaan } \\
\text { Panas Bumi }\end{array}$ & $17 \%$ & $83 \%$ & $\begin{array}{l}\text { Pengetahuan } \\
\text { Kurang }\end{array}$ & $9 \%$ & $91 \%$ & $\begin{array}{l}\text { Pengetahuan } \\
\text { Kurang }\end{array}$ \\
\hline $\begin{array}{l}\text { Pengaruh Eksplorasi Panas } \\
\text { bumi terhadap Kondisi } \\
\text { Lingkungan }\end{array}$ & $57 \%$ & $43 \%$ & $\begin{array}{l}\text { Pengetahuan } \\
\text { Kurang }\end{array}$ & $58 \%$ & $42 \%$ & $\begin{array}{l}\text { Pengetahuan } \\
\text { Kurang }\end{array}$ \\
\hline $\begin{array}{l}\text { Pengaruh Eksplorasi Panas } \\
\text { bumi terhadap Kondisi } \\
\text { Ekonomi }\end{array}$ & $92 \%$ & $8 \%$ & $\begin{array}{l}\text { Pengetahuan } \\
\text { Cukup }\end{array}$ & $90 \%$ & $10 \%$ & $\begin{array}{l}\text { Pengetahuan } \\
\text { Cukup }\end{array}$ \\
\hline $\begin{array}{l}\text { Pengaruh Eksplorasi Panas } \\
\text { bumi terhadap Kondisi } \\
\text { Sosial Masyarakat }\end{array}$ & $45 \%$ & $55 \%$ & $\begin{array}{l}\text { Pengetahuan } \\
\text { Kurang }\end{array}$ & $36 \%$ & $64 \%$ & $\begin{array}{l}\text { Pengetahuan } \\
\text { Kurang }\end{array}$ \\
\hline Rataan & $48 \%$ & $52 \%$ & $\begin{array}{l}\text { Pengetahuan } \\
\text { Kurang }\end{array}$ & $46 \%$ & $54 \%$ & $\begin{array}{l}\text { Pengetahuan } \\
\text { Kurang }\end{array}$ \\
\hline
\end{tabular}

(Sumber: Data Primer, 2016) 
karena pengambilan data dilakukan pada siang hari di pertengahan minggu sehingga banyak kepala keluarga yang sedang berada di luar rumah untuk bekerja. Sementara berkaitan dengan lokasi desa dan tingkat ekonomi, mayoritas penduduk desa hanya mampu bersekolah hingga pendidikan dasar, $71 \%$ responden Desa Pajambon adalah lulusan Sekolah Dasar (SD) dan 20\% lulusan Sekolah Menengah Pertama (SMP). Hanya $7 \%$ responden yang tercatat sebagai lulusan Sekolah Menengah Atas (SMA) dan 2\% lulusan universitas. Responden Desa Cisantana memiliki tingkat pendidikan sedikit lebih baik, terdapat $8 \%$ responden yang merupakan lulusan universitas, bahkan $2 \%$ lulusan magister. Namun, mayoritas responden adalah tamatan SD (64\%) dan SMP (16\%). Tingkat pendidikan responden dan masyarakat akan memberikan pengaruh pada tingkat pengetahuan dan persepsi terhadap kegiatan eksplorasi panas bumi.

Hasil pengukuran tingkat pengetahuan masyarakat eksplorasi panas bumi berdasarkan intrepetasi pertanyaan kuisioner dipaparkan pada Tabel 6 dan Tabel 7.

Secara keseluruhan sesuai hasil perhitungan kategori pengetahuan yang telah dipaparkan pada metode penelitian, kedua desa belum memiliki pengetahuan yang cukup tentang rencana eksplorasi panas bumi. Sebanyak 93\% responden Desa Pajambon dan 94\% responden Desa Cisantana hanya memiliki pengetahuan yang cukup tentang akan dilakukannya eksplorasi panas bumi yang informasinya tersebar melalui media massa, organisasi masyarakat dan pembicaraan antar warga. Sementara pengetahuan masyarakat kedua desa mengenai lokasi, pemrakarsa dan sosialisasi panas bumi masih dikategorikan kurang. Masyarakat kedua desa memiliki tingkat pengetahuan yang kurang mengenai beberapa aspek rencana eksplorasi panas bumi. Kurangnya tingkat pengetahuan mengenai lokasi eksplorasi didasarkan pada jawabanjawaban responden yang mayoritas tidak mengetahui lokasi pasti dimana eksplorasi akan dilakukan, namun hanya mengetahui bahwa eksplorasi kemungkinan akan dilakukan disekitar mata air panas yang terletak di sebelah utara permukiman warga. Salah seorang responden menyatakan bahwa terdapat isu yang beredar mengenai perubahan lingkungan di sekitar mata air panas yang tersebar di Gunung Ciremai sehingga masyarakat khawatir seluruh area gunung akan dikomersilkan menjadi WKP. Namun, bila dilakukan perbandingan, Desa Pajambon memiliki tingkat pengetahuan yang lebih baik dibanding Desa Cisantana mengenai lokasi eksplorasi panas bumi, hal ini berkaitan dengan lokasi titik pengeboran yang terletak di wilayah administrasi Desa Pajambon, selain itu pihak pemrakarsa pun beberapa kali melakukan survey di daerah sekitar lokasi yang akan dijadikan pengeboran. Sehingga sedikit banyak memberikan gambaran lokasi pada masyarakat Desa Pajambon.

Masyarakat kedua desa masih memiliki tingkat pengetahuan yang kurang mengenai definisi dan pengaruh kegiatan eksplorasi panas bumi secara umum. Masyarakat Desa Cisantana dan Desa Pajambon tidak memiliki pengetahuan mengenai definisi, ciri lokasi panas bumi dan dampaknya terhadap aspek lingkungan dan sosial secara komprehensif. Ketimpangan tingkat pengetahuan masyarakat terjadi pada butir pertanyaan pengetahuan masyarakat mengenai pengaruh eksplorasi terhadap kondisi ekonomi jika dibandingkan dengan tingkat pengetahuan masyarakat terhadap dampak kondisi sosial dan dampak terhadap lingkungan, 92\% responden dari Desa Pajambon dan 90\% reponden Desa Cisantana mengetahui dengan pasti pengaruh yang akan diberikan oleh eksplorasi terhadap kondisi ekonomi masyarakat.

Sebagian besar masyarakat sepakat bahwa rencana eksplorasi akan memberikan dampak negatif terhadap kondisi perekonomian. Menurut pengetahuan masyarakat, eksplorasi panas bumi akan menurunkan produktivitas pertanian mereka, khususnya komoditas yang dikembangkan di Desa Pajambon yakni buah jambu merah. Masyarakat menilai adanya eksplorasi akan menyebabkan peningkatan suhu udara, penurunan kuantitas air. Sehingga dikhawatirkan mengganggu kesuburan tanaman. Walaupun eksplorasi memungkinkan adanya lapangan pekerjaan baru, masyarakat sekitar merasa bahwa kualifikasi untuk bisa mendapatkan lapangan pekerjaan baru akan sulit, karena mayoritas tingkat pendidikan masyarakat yang yang masih rendah. Sehingga dalam pengetahuan mayarakat, rencana eksplorasi panas bumi hampir tidak akan memberikan dampak yang positif terhadap perekonomian yang langsung bisa dirasakan masyarakat untuk jangka waktu lama.

Persepsi dan Penerimaan Masyarakat Terhadap Rencana Eksplorasi Panas bumi

Hasil analisis kuisioner mengenai persepsi masyarakat di kedua desa menujukan secara signifikan bahwa masyarakat yang diwakili oleh responden jelas tidak menyetujui adanya rencana eksplorasi, analisis dipaparkan pada Tabel 8.

Persepsi penerimaan merupakan tujuan utama dari pengumpulan data sosial yang dilakukan, persepsi setuju dan tidak setuju yang diberikan oleh masyarakat dapat memberikan gambaran mengenai tinggi rendahnya tingkat penerimaan masyarakat terhadap kegiatan ekslporasi panas bumi. Pertanyaan mengenai persepsi setuju dan tidak setuju adalah pertanyaan tertutup dengan dua opsi jawaban.

Berdasarkan Tabel 8, Desa Pajambon dan Desa Cisantana tidak menyetujui adanya rencana eksplorasi panas bumi yang dilakukan di lingkungan sekitar desa. Hampir 75\% responden menyatakan keberatan akan rencana eksplorasi panas bumi, jumlah ini dapat dikategorikan tinggi karena sekitar tiga perempat masyarakat tidak setuju dengan rencana eksplorasi. Lebih dari 90\% masyarakat kedua desa memiliki pengetahuan tentang adanya rencana eksplorasi panas 
Agie S. Gizawi, dkk/Majalah Geografi Indonesia, Vol. 31 No.1, Maret $2017: 1$ - 11

Tabel 8. Persepsi Masyarakat Desa Pajambon dan Desa Cisantana terhadap Pengaruh Rencana Eksplorasi Panas Bumi

\begin{tabular}{|c|c|c|c|c|c|c|c|c|}
\hline \multirow[t]{2}{*}{ Aspek Persepsi } & \multicolumn{3}{|c|}{$\begin{array}{c}\text { Persentase Persepsi Masyarakat Desa } \\
\text { Pajambon }\end{array}$} & \multirow[t]{2}{*}{ Kategori } & \multicolumn{3}{|c|}{$\begin{array}{l}\text { Persentase Persepsi Masyarakat Desa } \\
\text { Cisantana }\end{array}$} & \multirow[t]{2}{*}{ Kategori } \\
\hline & $\begin{array}{l}\text { Mem- } \\
\text { berikan } \\
\text { Pengaruh } \\
\text { Negatif }\end{array}$ & $\begin{array}{l}\text { Tidak } \\
\text { Mem- } \\
\text { berikan } \\
\text { Pengaruh }\end{array}$ & $\begin{array}{l}\text { Mem- } \\
\text { berikan } \\
\text { Pen- } \\
\text { garuh } \\
\text { Positif }\end{array}$ & & $\begin{array}{l}\text { Mem- } \\
\text { berikan } \\
\text { Pengaruh } \\
\text { Negatif }\end{array}$ & $\begin{array}{c}\text { Tidak } \\
\text { Memberikan } \\
\text { Pengaruh }\end{array}$ & $\begin{array}{l}\text { Mem- } \\
\text { berikan } \\
\text { Pengaruh } \\
\text { Positif }\end{array}$ & \\
\hline $\begin{array}{l}\text { Pengaruh terhadap } \\
\text { kondisi lingkungan, } \\
\text { kualitas dan kuantitas } \\
\text { airtanah }\end{array}$ & $39,5 \%$ & $57,0 \%$ & $3,5 \%$ & $\begin{array}{l}\text { Eksplor- } \\
\text { asi Tidak } \\
\text { Memberikan } \\
\text { Pengaruh }\end{array}$ & $44,9 \%$ & $51,0 \%$ & $4,1 \%$ & $\begin{array}{l}\text { Eksplor- } \\
\text { asi Tidak } \\
\text { Memberikan } \\
\text { Pengaruh }\end{array}$ \\
\hline $\begin{array}{l}\text { Pengaruh terhadap } \\
\text { kondisi lingkungan, } \\
\text { kualitas dan kuantitas } \\
\text { tutupan vegetasi }\end{array}$ & $47,7 \%$ & $45,3 \%$ & $7,0 \%$ & $\begin{array}{l}\text { Eksplorasi } \\
\text { Memberikan } \\
\text { Pengaruh } \\
\text { Negatif }\end{array}$ & $57,1 \%$ & $40,8 \%$ & $2,0 \%$ & $\begin{array}{l}\text { Eksplorasi } \\
\text { Memberikan } \\
\text { Pengaruh } \\
\text { Negatif }\end{array}$ \\
\hline $\begin{array}{l}\text { Pengaruh terhadap } \\
\text { kondisi lingkungan, } \\
\text { berubahnya penggu- } \\
\text { naan lahan }\end{array}$ & $54,7 \%$ & $38,4 \%$ & $7,0 \%$ & $\begin{array}{l}\text { Eksplorasi } \\
\text { Memberikan } \\
\text { Pengaruh } \\
\text { Negatif }\end{array}$ & $43,9 \%$ & $54,1 \%$ & $2,0 \%$ & $\begin{array}{l}\text { Eksplor- } \\
\text { asi Tidak } \\
\text { Memberikan } \\
\text { Pengaruh }\end{array}$ \\
\hline $\begin{array}{l}\text { Memberikan lapan- } \\
\text { gan pekerjaan (men- } \\
\text { gurangi penganggu- } \\
\text { ran) di daerah sekitar } \\
\text { lokasi eksplorasi }\end{array}$ & $34,9 \%$ & $48,8 \%$ & $16,3 \%$ & $\begin{array}{l}\text { Eksplor- } \\
\text { asi Tidak } \\
\text { Memberikan } \\
\text { Pengaruh }\end{array}$ & $36,7 \%$ & $52,0 \%$ & $11,2 \%$ & $\begin{array}{l}\text { Eksplor- } \\
\text { asi Tidak } \\
\text { Memberikan } \\
\text { Pengaruh }\end{array}$ \\
\hline $\begin{array}{l}\text { Mengubah harga la- } \\
\text { han di daerah sekitar } \\
\text { lokasi eksplorasi }\end{array}$ & $1,2 \%$ & $38,4 \%$ & $60,5 \%$ & $\begin{array}{l}\text { Eksplorasi } \\
\text { Memberikan } \\
\text { Pengaruh } \\
\text { Positif }\end{array}$ & $0,0 \%$ & $44,9 \%$ & $55,1 \%$ & $\begin{array}{l}\text { Eksplorasi } \\
\text { Memberikan } \\
\text { Pengaruh } \\
\text { Positif }\end{array}$ \\
\hline $\begin{array}{l}\text { Berpengaruh } \\
\text { terhadap kualitas kes- } \\
\text { ehatan masyarakat di } \\
\text { daerah sekitar lokasi } \\
\text { eksplorasi }\end{array}$ & $17,4 \%$ & $75,6 \%$ & $7,0 \%$ & $\begin{array}{l}\text { Eksplor- } \\
\text { asi Tidak } \\
\text { Memberikan } \\
\text { Pengaruh }\end{array}$ & $27,6 \%$ & $70,4 \%$ & $2,0 \%$ & $\begin{array}{l}\text { Eksplor- } \\
\text { asi Tidak } \\
\text { Memberikan } \\
\text { Pengaruh }\end{array}$ \\
\hline $\begin{array}{l}\text { Berpengaruh terha- } \\
\text { dap pembangunan } \\
\text { infrastruktur di } \\
\text { daerah sekitar lokasi } \\
\text { eksplorasi }\end{array}$ & $8,1 \%$ & $58,1 \%$ & $33,7 \%$ & $\begin{array}{l}\text { Eksplor- } \\
\text { asi Tidak } \\
\text { Memberikan } \\
\text { Pengaruh }\end{array}$ & $6,1 \%$ & $43,9 \%$ & $50,0 \%$ & $\begin{array}{l}\text { Eksplorasi } \\
\text { Memberikan } \\
\text { Pengaruh } \\
\text { Positif }\end{array}$ \\
\hline $\begin{array}{l}\text { Berpengaruh terh- } \\
\text { adap kualitas dan } \\
\text { kuantitas pemukiman } \\
\text { di daerah sekitar } \\
\text { lokasi eksplorasi }\end{array}$ & $18,6 \%$ & $73,3 \%$ & $8,1 \%$ & $\begin{array}{l}\text { Eksplor- } \\
\text { asi Tidak } \\
\text { Memberikan } \\
\text { Pengaruh }\end{array}$ & $33,7 \%$ & $62,2 \%$ & $4,1 \%$ & $\begin{array}{l}\text { Eksplor- } \\
\text { asi Tidak } \\
\text { Memberikan } \\
\text { Pengaruh }\end{array}$ \\
\hline
\end{tabular}

bumi di kawasan sekitar desa, berdasarkan analisis $74,5 \%$ dan $75,5 \%$ responden yang tidak setuju akan rencana eksplorasi termasuk ke dalam responden dengan pengetahuan cukup tentang adanya rencana ini walau tidak memiliki pengetahuan cukup mengenai pengaruh nyata dari kegiatan eksplorasi.

Ketidakmengertian dan terbatasnya pemahaman masyarakat menggiring terhadap ketidaksetujuan akan rencana eksplorasi. Tingginya persentase ketidaksetujuan akan rencana eksplorasi disebabkan oleh tidak adanya sosialisasi yang dilakukan pemerintah sehingga masyarakat memiliki keterbatasan informasi yang valid terkait kegiatan panas bumi. Informasi yang diperoleh masyarakat lebih banyak didapatkan dari kajian kajian yang dilakukan oleh LSM yang mengarahkan persepsi masyarakat pada dampak dampak negatif dari kegiatan eksplorasi panas bumi. Sehingga informasi yang diserap masyarakat tidak berimbang dan menimbulkan persepsi yang negatif.

Beberapa alasan utama yang menyebabkan ketidaksetujuan masyarakat adalah aspek ekonomi, ketakutankebencanaan dan sentimen asing. Aspek ekonomi menjadi penyebab utama yang memberatkan masyarakat untuk setuju terhadap rencana eksplorasi. Masyarakat menganggap bahwa kegiatan tersebut dapat menurunkan produktivitas pertanian, yang akan berbanding lurus dengan penurunan pendapatan. Masyarakat menganggap bahwa eksplorasi panas bumi yang akan dilakukan dapat menyebabkan bencana yang serupa dengan yang terjadi di daerah Sidoarjo. Terdapat juga beberapa responden yang menyatakan ketidak setujuannya terhadap kegiatan ini berdasarkan sentimen 
Tabel 9. Tingkat Penerimaan Masyarakat Desa Pajambon dan Desa Cisantana terhadap Rencana Eksplorasi Panas bumi

\begin{tabular}{|c|c|c|c|c|c|c|}
\hline \multirow[t]{2}{*}{ Desa } & \multirow[t]{2}{*}{ Aspek Persepsi } & \multicolumn{2}{|c|}{ Jumlah Responden (ind) } & \multicolumn{2}{|c|}{ Persentase (\%) } & \multirow[t]{2}{*}{ Kategori } \\
\hline & & $\begin{array}{l}\text { Menyetujui Rencana } \\
\text { Eksplorasi }\end{array}$ & $\begin{array}{l}\text { Tidak Menyetujui } \\
\text { Rencana Eksplorasi }\end{array}$ & $\begin{array}{l}\text { Menyetujui Rencana } \\
\text { Eksplorasi }\end{array}$ & $\begin{array}{l}\text { Tidak } \\
\text { Menyetujui } \\
\text { Rencana Ek- } \\
\text { splorasi }\end{array}$ & \\
\hline Desa Pajambon & $\begin{array}{l}\text { Menyutujui } \\
\text { adanya rencana } \\
\text { eksplorasi } \\
\text { panas bumi }\end{array}$ & 22 & 64 & $25.6 \%$ & $74,4 \%$ & $\begin{array}{l}\text { Tidak } \\
\text { Menyetujui } \\
\text { Rencana } \\
\text { Eksplorasi }\end{array}$ \\
\hline Desa Cisantana & $\begin{array}{l}\text { Menyutujui } \\
\text { adanya rencana } \\
\text { eksplorasi } \\
\text { panas bumi }\end{array}$ & 25 & 73 & $25,5 \%$ & $74,5 \%$ & $\begin{array}{l}\text { Tidak } \\
\text { Menyetujui } \\
\text { Rencana } \\
\text { Eksplorasi }\end{array}$ \\
\hline
\end{tabular}

asing khususnya terhadap perusahaan pemenang lelang yang berasal dari Amerika. Selain itu, informasi mengenai luasan yang akan dijadikan lokasi eksplorasi panas bumi yang beredar di masyarakat adalah seluas $24.000 \mathrm{Ha}$ sehingga masyarakat menganggap bahwa kegiatan ini akan menyebabkan mereka direlokasi bahkan hingga keluar Jawa. Alasan-alasan tersebut berkembang luas di masyarakat dan sedikit-banyak menjadi opini kolektif yang menyebabkan sebagian besar masyarakat di kedua desa menolak adanya rencana eksplorasi panas bumi.

Untuk mengubah persepsi atau meluruskan kesalahfahaman konsep pada masyarakat, upaya sosialisasi dengan frekuensi tinggi dan penetrasi ke seluruh lapisan masyarakat adalah upaya utama yang dapat dilakukan sebagai strategi minimalisir konflik antara rencana eksplorasi dan penolakan masyarakat. Memberikan penjelasan kepada masyarakat melalui sosialisasi tentang krisis energi dan pentingnya keberadaan sumber energi terbarukan seperti panas bumi merupakan langkah penting. Penjelasan diberikan harus dalam bahasa sesederhana mungkin sehingga mampu difahami oleh tingkat pendidikan masyarakat yang rendah. Selain itu, mengusahakan koordinasi antara pihak pemerintah dan PLN sebagai distributor energi listrik dari PLTP untuk memberikan tarif dasar listrik yang lebih rendah bagi masyarakat sekitar lokasi PLTP sebagai timbal-balik gangguan dan potensi kebencanaan akibat kegiatan eksplorasi dan eksploitasi adalah salah satu strategi yang dapat dilaksanakan sebagai bentuk insentif pada potensi perubahan yang terjadi di sekitar lokasi eksplorasi.

\section{KESIMPULAN}

Analisis perubahan ekologi bentanglahan dilakukan pada tiga aspek yakni luas permukaan bentanglahan, tereduksinya kawasan ekosistem penting dan adanya fragmentasi akibat rencana kegiatan eksplorasi panasbumi. Berdasarkan sistem rating SLIA per aspek dan secara keseluruhan, kegiatan eksplorasi panas bumi WKP G. Ciremai memberikan dampak yang sangat rendah terhadap perubahan bentanglahan lokasi eksplorasi. Walau secara biofisik kegiatan eksplorasi dikategorikan tidak memberikan dampak, akan tetapi kegiatan ini mendapat penolakan dari masyarakat sekitar yang berpresepsi bahwa kegiatan eksplorasi akan mempengaruhi beberapa aspek penghidupan masyarakat seperti aspek lingkungan dan ekonomi. Ketidaksetujuan masyarakat terhadap rencana kegiatan eksplorasi tidak diikuti oleh cukupnya pengetahuan mengenai panas bumi, dampaknya dan rincian kegiatan eksplorasi. Rencana eksplorasi panasbumi tidak sepenuhnya dipahami masyarakat. Sehingga masyarakat memiliki pandangan yang negatif dan berujung pada tingkat penerimaan yang rendah. Oleh karena itu perlu ada edukasi dan sosialisasi yang lebih intensif terkait panasbumi tersebut. Baik yang berkenaan dengan definisi, teknologi yang digunakan, hingga dampak yang ditimbulkan.

\section{DAFTAR PUSTAKA}

Farina, A. (1998). Principals and methods in landscape ecology. Chapman \& Hall Ltd. London.

Foth, H.D. (1984). Fundamental of Soil Science. John Willey and Sons, New York.

Handayani, W. dan Y. Indrajaya. (2007). Jasa Lingkungan Hutan Rakyat: Peluang Penerapan Imbal Jasa. Prosiding Seminar Hasil Penelitian dan Pengembangan Hasil Hutan. Pusat Penelitian dan Pengembangan Hasil Hutan, Badan Penelitian dan Pengembangan Kehutanan, Departemen Kehutanan. Bogor. Hal. 398-449.

Otsman, David. (2015). A New Approach for Assessing Landscape Impacts of Geothermal Power Plants. Reykjavik: Faculty of Life and Environmental Sciences School of Engineering and Natural Sciences University of Iceland

Schwab, G.O., Fangmeir, D.D., Elliot, W.J., and Frevert, R.K. (1992). Soil ang Water Conservation Engineering. Four Edition, John Wiley \& Sons. Inc, New York.

Susanto, R.H. dan Purnomo, R.H (pentenjemah). (1997). Teknik Konservasi Tanah dan Air. CFWMS Sriwijaya University, Palembang.

Soesetijo, Sis. (2014).Analisis Hubungan Kausalitas antara Konsumsi Daya Listrik dan Trafik Internet 
Spasial Kampus

Utaya, Sugeng. (2008). Pengaruh perubahan penggunaan lahan terhadap sifat biofisik tanah dan kapasitas infiltrasi di kota Malang. Forum Geografi, Vol. 22, No. 2, Desember 2008: 99-112.

Wangke, M.W. (2010). Persepsi Masyarakat Terhadap Kegiatan Pengembangan Lapangan Uap dan PLTP Unit 5 dan 6 PT PERTAMINA GEOTHERMAL ENERGY.

Widyastuti, Arie. (2006). Analisis Kelayakan Proyek Pembangkit Listrik Energi Panas bumi dengan Menggunakan Capital Budgeting Technique. 